\title{
OPPORTUNITY LOSS ANALYSIS OF DISCHARGE AGAINST MEDICAL ADVICE (DAMA) AT INPATIENT UNIT OF TYPE A HOSPITAL IN SURABAYA
}

\author{
Analisis Opportunity Loss Pasien Pulang Paksa di Instalasi Rawat Inap \\ Rumah Sakit Tipe A Surabaya \\ Seta Prakoso1, *Nabilah Bilqis² \\ ${ }^{1}$ National Population and Family Planning Board (BKKBN), Indonesia \\ ${ }^{2}$ Faculty of Public Health, Universitas Airlangga, Indonesia \\ *Correspondence: st.prakoso@gmail.com, nabilah.bilqis-2016@fkm.unair.ac.id
}

\begin{abstract}
Background: Patients who Discharge Against Medical Advice (DAMA) will experience the opportunity loss. DAMA will result in opportunity loss for patients to get treatment and cure their illness. For hospitals, DAMA patients will cause the opportunity loss for hospitals to provide services to patients.

Aim: The purpose of this research was to analyze the opportunity loss as the result of DAMA patient.

Methods: The method used in this research was a descriptive research. The samples were chosen from the total sample of inpatient population who did DAMA as many as 77 medical records. The inclusive samples were doctors who were responsible for other doctors and dentists as well as inpatient medical records. Meanwhile, the exclusive samples were doctors who are not responsible for other doctors and dentists as well as inpatient medical records. Data analysis used Microsoft Excel to see the total and percentage of DAMA patients.

Results: The number of DAMA patients was 77 patients. The highest number of DAMA patients was those in grade 3 as many as $25 \%$. It happened because the grade 3 was cheaper than others. As many as $65 \%$ of DAMA patients paid hospital fees using general payments. Patients felt free to discharge themselves from the hospitals because they funded on their own. The majority of DAMA patients were type 2 DM patients amounted to $12 \%$ because they assumed they could carry out self-care at home.

Conclusions: DAMA patients caused opportunity loss and no Social Security Agency for Health (BPJS Kesehatan) guarantees. Therefore, the hospital has to form a policy to prevent patients from DAMA, notify and ask patients' reasons of doing DAMA, so the hospital can use these as information for hospital service evaluation.
\end{abstract}

Keywords: Opportunity loss, DAMA, Hospital.

\section{ABSTRAK}

Latar Belakang: Pasien yang melakukan pulang paksa akan menyebabkan kesempatan yang hilang. Tindakan pulang paksa akan mengakibatkan hilangnya kesempatan pasien untuk mendapatkan perawatan dan kesembuhan penyakit yang diderita. Bagi rumah sakit, tindakan pasien pulang paksa akan mengakibatkan hilangnya kesempatan bagi rumah sakit untuk menyediakan pelayanan kepada pasien.

Tujuan: Tujuan dari penelitian ini adalah menganalisis kesempatan yang hilang yang menyebabkan pasien pulang paksa.

Metode: Penelitian ini merupakan penelitian deskriptif. Teknik pengambilan sampel menggunakan total sampling sebanyak populasi pasien rawat inap yang melakukan pulang paksa. Jumlah populasi yang diteliti adalah 77 rekam medis rawat inap. Kriteria untuk sampel inklusi adalah dokter yang bertanggung jawab untuk setiap Staf Medik Fungsional (SMF) dan rekam medis rawat inap, sedangkan kriteria sampel eksklusi bukan dokter yang bertanggung jawab untuk setiap SMF dan bukan rekam medis rawat inap. Analisis data menggunakan Micosoft Excel untuk melihat jumlah dan persentase pasien pulang paksa.

Hasil: Jumlah pasien pulang paksa sebanyak 77 pasien, terbanyak terdapat di kelas 3 sebanyak 25\% pasien pulang paksa karena kelas 3 lebih murah biayanya dibandingkan kelas lainnya. Sebanyak $65 \%$ pasien pulang paksa membayar biaya rumah sakit menggunakan pembayaran umum, pasien merasa berhak menentukan kepulangannya karena membayar sendiri. Mayoritas pasien pulang paksa sebanyak $12 \%$ merupakan pasien DM tipe 2 yang melakukan pulang paksa karena anggapan pasien bisa melakukan perawatan sendiri di rumah.

Kesimpulan: Pasien yang melakukan kegiatan pulang paksa menyebabkan kesempatan yang hilang serta tidak mendapatkan jaminan dari BPJS. Oleh karena itu, rumah sakit harus membuat kebijakan untuk mencegah terjadinya pasien melakukan pulang paksa, memberitahu dan menanyakan alasan pasien melakukan pulang paksa sehingga dapat dijadikan informasi untuk evaluasi pelayanan rumah sakit.

Kata Kunci: Kesempatan yang hilang, Pasien pulang paksa, Rumah sakit. 


\section{INTRODUCTION}

DAMA (Discharge Against Medical Advice) incidence is one of indicator for inpatient service quality Based on the minimum service standards formed by Regulation of Ministry of Health No. 28 of 2008, the discharging rate from hospitals should be $\leq 5 \%$ of all patients in the period. Discharge Against Medical Advice (DAMA) is defined as discharged patients from a hospital or other health care facilities before the doctor who treats them allows them to go home. This discharging incidence is important to discuss because patients who discharge themselves before recovery will impact other people's perceptions about the hospital (Atmiroseva and Nurwahyuni, 2017).

Type A hospital in Surabaya is a hospital owned by the East Java Provincial Government which now changes its name into a Local Public Service Agency or Badan Layanan Umum Daerah $(B L U D)$. The Inpatient Unit of type A hospital in Surabaya has Human Resources (HR) consisting of 141 medical and non-medical personnels and 163 beds. The Bed Occupancy Rate (BOR) of type A hospital in Surabaya was quite large nearly $79 \%$ in 2009. In August 2009, patients discharged themselves just about $1 \%$ as suitable with the target of type A hospital in Surabaya. Then, it increased in October 2009 to $2.4 \%$, and having increased again in December 2009, the number of discharged patients reached the hospital quality goal in February 2010 and rebounded again in the following month. The total number of DAMAs in 2010 was $9 \%$ out of the total inpatients. It exceeded the hospital's target of $5 \%$ out of the total outpatients. The high number of DAMAs at type A hospital in Surabaya reached $9 \%$ exceeding the hospital's target of $5 \%$. The principal reasons of DAMA patients include relief of symptoms (19.4\%), financial problems (16.1\%), distant home from the hospital (16.1\%), dissatisfaction with the service (12.9\%) and work obligations (9.7\%) (Ak, S and Z, 2016).

Patients who had insurance policies chose to discharge themselves to end the financial support, which explains why the majority of DAMA patients were uninsured or not covered by any medical aid. One example is that the National Health Insurance (NHI) can be an assistance, but it does not cover all aspects of management. Besides, it is currently applicable to federal workers who constitute a minor fraction of the total work force in Nigeria (Popoola et al., 2013).

The present study identified financial constraints as the most common reason for DAMA.This study reported that parents had difficulty in paying the medical treatment for their children in Nigeria. It would not be suprising if it was considered in terms of the weak health insurance schemes in most of developing countries. In contrast, Iran showed that financial constraints were ranked low among the parents' reasons for DAMA (Ndu et al., 2016).

Indonesia regulations regarding DAMAs before and after the National Health System or Jaminan Kesehatan Nasional (JKN) implementation are certainly different. Before the JKN (National Health Insurance) was implemented, the patients was forced to go home, but guaranteed by the insurance for the service costs. However, now if a patient is forced to go home without a doctor's recommendation, she will be perceived not to follow the procedures of Social Security Agency for Health or BPJS Kesehatan so that she will not get the cost reimbursement from BPJS Kesehatan and be considered as a general patient. The obstacle is that the number of discharged patients do not understand the regulation. If they feel recovered, they and their family will ask to go home without the doctor's recommendation. The miscommunication reported in media quickly led to patients' distrust on the BPJS Kesehatan system simply because the officers and patients did not converse about the regulation of DAMA. It is expected that the current BPJS Kesehatan regulations can be a factor suppressing the DAMA incidence. Other than that, because of a small amount of research on opportunity loss at inpatient unit of type A hospital in Surabaya, this research is important to conduct. The purpose of this study was to anlyze the opportunity loss as the result of DAMA patients.

\section{METHOD}

Based on the phenomena, this research was a descriptive study. Observations were conducted on the opportunity loss due to the DAMA at the Inpatient Unit of type A hospital in Surabaya. This research used a descriptive method.

The research collected the data at type $A$ hospital in Surabaya, on Manyar Kertoadi Street Surabaya, East Java. The initial data collection was carried out from November to December 2010 while the research time was done from February to March 2012. Additional data collection was conducted from July to August 2012. The primary data were obtained from interviews with doctors at each department based on the diagnosis number of DAMA patients. Primary data collected were information from health workers about patients' reasons for doing DAMA. The secondary data were obtained from observation on the medical record data of DAMAs at inpatient units for one-month examination. Secondary data were collected from rooms where patients did DAMA, diagnosis, and payment to use.

The inclusive samples were doctors who are responsible for other doctors and dentists as well as inpatient medical records. Whereas, the exclusive samples were doctors who are not responsible for other doctors and dentists as well as inpatient medical records. The samples were the same as the inpatient population who did DAMA. There were 77 medical records overall. 
The ethical clearence was conducted at type A hospital in Surabaya, and the research was declared ethical. Before conducting the research, the hospital agreed to give the data of DAMA patients by signing the informed consent. The data were analyzed by observing types of payments, room type, patient diagnosis, length of stay at a hospital, supporting medical facilities used by patients, the length of stay recommended by doctors, and supporting medical facilities needed by patients. The next step is the medical record data of DAMA patients was obtained after one-month observation at the hospital. The data of service standards and interviews with doctors gave information about the recommended length of stay and needed facilities. The research on the medical records of discharged patients found that the stay duration at the hospital and the facilities obtained by the patients. The comparison between the service standards and the medical record data showed the opportunity loss as the result of DAMA patients.

\section{RESULTS AND DISCUSSION}

\section{Discharge Against Medical Advice}

DAMA patients are patients or their family requesting to go home before being recommended by a doctor. The standard incidence of DAMA at the hospital should be $\leq 5 \%$ (Widiarti, Lestari and RMD, 2014). According to Regulation of Ministry of Health No. 28 Year 2014 about Guidelines for the Implementation of National Health Insurance Program Chapter IV letter C point 2, health services that do not comply with the procedures will not be guaranteed by BPJS (Ministry of Health of the Republic of Indonesia, 2014).

When DAMA occurs, it will cause an opportunity loss for the patients and the hospital. DAMA will result in the patient's opportunity loss to get treatment and cure their illness. Moreover, the DAMA incidences will fail the hospitals to provide services to patients. The patients will lose the opportunity of using the hospital facilities, medical and non-medical personnel at the hospital, inpatient rooms, drugs and hospital pharmacy.

According to Azami-Aghdash et al. (2016), they determined some of the most important factors of DAMA in Pakistan including male sex, young patients, addicted patients, alcoholism, and low socioeconomic patients. Then, the patients feel their conditions better than before, dissatisfaction with the service performance and quality, also financial problems because of the long hospitalization despite the insurance coverage were the primary causes of repatriation. The discharging patients can cause the increase of the same diagnosis, complications, morbidity, mortality, and healthcare costs. Therefore, the effective interventions may reduce these results (Azami-Aghdash et al., 2016).

Also, several vital complaints related to the high rates of DAMA involve nonspecific chest pain, abdominal pain, headache, nausea, and vomiting. The reasons for the majority of discharged patients with severe diagnoses include a long examination for patients at Emergency Department (ED), invasive procedures, a long wait, and discomfort (Sayed et al., 2016).

Studies that examine outcomes (return visits, hospitalizations, and mortality) of patients who discharge themselves from hospitals are often limited by the poor response rates, small sample size, or lack of a valid comparison group. However, most of discharged patients were those who experienced unbearable pain and wanted to be treated at home because they felt more comfortable. The patients who are at risk of suffering from the side effects of the treatment are also more likely to return to the emergency room and to be hospitalized in a short time after the first visit. A study conducted by Robinson and Lam (2013) found that the discharged patients reached $24.4 \%$ of all ED patients who returned to the hospital.

\section{Opportunity Loss}

Making decision must be careful, so someone will not forget the importance of information and regret what they have decided. Information about what to choose can reduce the disappointment in the future. The lack of information about the choices will lead to errors. Selection errors will result in an opportunity loss. Opportunity loss is a gap between the values patients can get and the values that the patients can get more. Therefore, to minimize the opportunity loss, the decision makers have to decide based on their needs (Xu, Yan and Chan, 2017).

According to Xu, Yan and Chan (2017), opportunity loss is defined as a potential opportunity and wasteful choice as a result of taking the best alternative decisions. Opportunity loss is a benefit or value that can be generated if used for something else (Sayed et al., 2016). In conclusion, opportunity loss is the choice loss as a result of decision-making by the discharged patients. The choice loss for treatment and services will risk the patients in the future. It is common that a few DAMA patients with the same disease diagnosis return to the hospital and request for treatment.

\section{Social Security Agency for Health Regulation Regarding DAMA}

The rolling out of government's free care scheme or Jamkesmas program since 2014 to JKN, should reduce the DAMA incidences as the costs are guaranteed for the cardholders to reduce the expense. As a result, it can make the prevalence of DAMA at inpatient unit of type $A$ hospital in Surabaya suppressed. The end of early treatment due to DAMA will affect the service utilization, examination and procedures. Thus, the repetitive treatments are carried out from the beginning again, so they affect the increase of health finance, and evaluation system of a disease (infectious diseases are more likely to be transmitted to others). 
The readmission causes over utilization, and the cost of health services is expensive because the patients repeat the service procedures. Readmission is important to investigate in this case. There were $14 \%$ of DAMA patients who came back with the same diagnosis and other diagnoses. This can be seen from 11 medical records that have not been returned to the officers. There were only 77 medical records out of 88 DAMA patients found. This certainly can be detrimental to patients and hospitals. The hospital must repeat the same procedures, and the patients will incur additional costs for treatment with the same diagnosis that should be cured in the previous treatment.

The research to find out why patients discharge from hospitals is important to conduct as an evaluation of health service quality. A study by Byun (2016) in United States showed no insurance for patients discharging against medical advice. Not only do the physicians have accurate information when negotiating with patients who have intention to leave, but also promote the effective communication. The primary reasons of DAMA include the symptoms relief $(19.4 \%)$, financial problems $(16.1 \%)$, distant home from hospital $(16.1 \%)$, dissatisfaction with care $(12.9 \%)$, and work obligations (9.7\%) (Ak, S and Z, 2016).

When JKN was implemented, BPJS users who were treated at inpatient unit had to comply with the procedures as stated in Regulation of Ministry of Health No.28 Year 2014 about guidelines for the implementation of the national health insurance program. In Chapter IV point $\mathrm{C}$ paragraph 2 , the regulation states that things that are not guaranteed in JKN program involve unprocedural health services. If patients discharge from hospitals without a doctor's consent, they will be considered general patients who need to pay the treatment on their own. Before JKN was implemented, patients who had been discharged and returned with similar disease diagnosis in a certain period were not served by the hospital, and thus they needed to look for another hospital to be treated. Lack of information about the information from the workers for managing health insurance or BPJS officers caused misinterpretation by patients who thought that the hospital does not accept the medical expenses using BPJS. Therefore, effective communication and routine socialization of various BPJS regulations are needed to avoid the rumors.

\section{DAMA based on Room Types}

The research was conducted at inpatient unit of type A hospital in Surabaya Surabaya from February 20, 2012 to 20 March 2012. From the data obtained, it is known that most of the patients were discharged from the hospital. Table 1 explains the data of returning patients in each room.
Table 1. DAMA based on Room Types in Type A Hospital Surabaya 20 February - 20 March 2012.

\begin{tabular}{lccc}
\hline $\begin{array}{c}\text { Room } \\
\text { Types }\end{array}$ & Bed & $\begin{array}{c}\text { Total } \\
\text { DAMA }\end{array}$ & Total Patient \\
\hline Marwah 1c & 15 & 7 & 394 \\
Marwah 2c & 30 & 16 & 666 \\
Marwah 3c & 28 & 22 & 747 \\
Marwah 4c & 28 & 11 & 666 \\
Shofa 2a & 14 & 3 & 189 \\
Shofa 3a & 24 & 12 & 537 \\
Shofa 4a & 17 & 3 & 465 \\
Noor afiah 2b & 20 & 4 & 471 \\
\hline Total & 176 & 88 & 4135 \\
\hline Source: Inpatient unit of type A hospital in Surabaya 2012
\end{tabular}

Based on the results, it is clear that 88 patients were discharged. When 88 medical records were examined, it was found that 77 medical records were DAMA patients. Meanwhile, 11 medical records were still not returned from each room. The limitations of this study are the unknown eleven medical records of patients which were not returned so that the researchers had difficulty to find information on the exact number of patients' readmission with the same diagnosis and exact number of patients with different diagnoses.

DAMA mostly occurs in room type 2 . Compared to room type $3,35.1 \%$ of patients in room type 2 were $1.3 \%$ much more than in type 3 . It may be due to unreturned eleven medical records. The discharged patients will cause an opportunity loss for the hospital because cost in each room will be different. To prevent the opportunity loss caused by DAMA, the patients should be informed about the importance of treatment. Also, the hospital can suggest them to move to other room types which are more affordable.

\section{DAMA by Payment Type}

Based on 77 medical records of DAMA patients, it can be seen that DAMA patients mostly used general payment.

Tabel 2. DAMA based on Payment Types at Type A Hospital in Surabaya from 20 February to 20 March 2012.

\begin{tabular}{lcc}
\hline \multicolumn{1}{c}{ Payment Types } & Total & Precentage \\
\hline General & 50 & $65 \%$ \\
$\begin{array}{l}\text { Sosial Insurance } \\
\text { (Jaringan Pengaman }\end{array}$ & 6 & $8 \%$ \\
$\begin{array}{l}\text { Sosial)-Jamkesmas } \\
\text { Province Government's }\end{array}$ & 3 & $4 \%$ \\
$\begin{array}{l}\text { Free Care Scheme } \\
\text { (JPS-SKM East Java) }\end{array}$ & & \\
$\begin{array}{l}\text { District Government's } \\
\text { Free Care Scheme } \\
\text { (JPS-SKM Surabaya }\end{array}$ & 6 & $8 \%$ \\
$\begin{array}{l}\text { Health Insurance) } \\
\text { Health Insurance for } \\
\text { Civil Servant (Askes) }\end{array}$ & 11 & $14 \%$ \\
Employee & 1 & $1 \%$ \\
\hline Source: Inpatient unit of type A hospital in Surabaya 2012
\end{tabular}


Out of 88 medical records of DAMA patients, there were only 77 medical records found at the medical record installation. Eleven medical records were not found with five of them unreturned and the other six borrowed by the officers in the room.

The number of DAMA was only $1.8 \%$ of 4135 inpatients. Even though $66.23 \%$ of discharged patients mostly paid using self-funds, and $33.77 \%$ of them used an insurance guarantee. The percentage of DAMAs was quite large because the discharged patients received insurance guarantees. Even though they were guaranteed by insurance, 26 of them were still discharged. In short, the payment factor is not the reason on why the patients were discharged. Other factors of DAMA include personal factors, hospital factors, and external factors from the hospital.

In contrast to BPJS regulations, the discharged patients were not guaranteed by the insurance, so they would be considered public patients with no health insurance. With such regulation, the number of DAMA and opportunity loss due to DAMA can decrease.

\section{DAMA Based on Disease Diagnosis}

Based on 77 medical records examined from February 20, 2012 to March 20, 2012, it was found that the disease diagnosis of DAMA patients was Diabetes Mellitus (DM) type 2.

Based on Table 3 , it is noticeable that 9 patients diagnosed to suffer from type 2 diabetes mellitus were discharged. In addition, 6 patients with febrile seizures and tuberculosis seizures got discharged. Meanwhile, there were five discharged patients diagnosed to have typhoid fever.

Based on 77 DAMA patients, most of DAMA patients got diagnosed to endured type 2 diabetes mellitus. There were also discharged patients with the dangerous disease diagnosis, such as HIV / AIDS. Form the disease diagnosis observed, if patients are less concerned about their health conditions, they will be more hazardous because their diseases are not treated as soon as possible. According to Glasgow et al. (2010), 32,819 of $1,898,128$ patients discharged would have $17.7 \%$ opportunity to return to the hospital in 30 days.

Bahadori et al. (2013) found 328 DAMA patients who had a $0.71 \%$ chance of dying compared to patients returning according to the procedures. The studies of Glasgow et al. and Bahadori et al. reinforce the results in this study that the discharged patients will aggravate their condition, even die. DAMA prevention can be minimized by explaining to patients and their families about the serious treatment that the patients should get to cure their health condition.

DAMA will cause an opportunity loss for the hospital to provide services to the discharged patients. The opportunity loss includes to the loss of providing treatment rooms, conducting laboratory test services, providing medical and nonmedical services, and serving medical support facilities.
Such opportunity loss will lead to the loss of opportunity cost, obtained by calculating the opportunity loss and the prevailing rates at type $A$ hospital in Surabaya.

Tabel 3. DAMA based on Diagnosis of Diseases in Surabaya Type A Hospital 20 February - 20 March 2012.

\begin{tabular}{|c|c|}
\hline Diagnosis of Diseases & Total Patient \\
\hline Febrile & 3 \\
\hline Malaria & 2 \\
\hline Thypoid fever & 5 \\
\hline Hepatitis C & 1 \\
\hline Hypocalemia & 1 \\
\hline Meningitis & 1 \\
\hline Nephrotic Syndrome & 1 \\
\hline HIV & 1 \\
\hline Dengue Haemoragic & 1 \\
\hline Syndrome & \\
\hline Dyspepsia & 2 \\
\hline Moderate Dehydration & 2 \\
\hline Acute Gastroenthritis & 3 \\
\hline Acute Diarrhea & 3 \\
\hline Salmonella Diarrhea & 2 \\
\hline Hypertension & 2 \\
\hline Diabetes Mellitus type 2 & $\overline{9}$ \\
\hline CVA infark & 1 \\
\hline CVA bleeding & 1 \\
\hline Vertigo & 2 \\
\hline Children Tuberculose & 1 \\
\hline Sinusitis maxilaris & 1 \\
\hline Acute Respiratory Infection & 3 \\
\hline Febrile seizures & 6 \\
\hline Tuberculose & 6 \\
\hline Chronic Bronchitis & 2 \\
\hline $\begin{array}{l}\text { Chronic Bronchitis and cor } \\
\text { pulmonal }\end{array}$ & 1 \\
\hline $\begin{array}{l}\text { Premature ventricular } \\
\text { contraction }\end{array}$ & 1 \\
\hline Asthma bronkiale & 1 \\
\hline Ureteric Stone & 1 \\
\hline $\begin{array}{l}\text { Chronic kidney failure and } \\
\text { anemia }\end{array}$ & 2 \\
\hline Urinary tract infections & 1 \\
\hline Mild head injury & 2 \\
\hline Low back pain & 1 \\
\hline Premature Parties & 1 \\
\hline Nasal fracture & 1 \\
\hline Acute Appendicitis & 1 \\
\hline Chronic Appendicitis & 1 \\
\hline Pulmonary Edema & 1 \\
\hline
\end{tabular}

DAMA based on Recommended Supporting Facilities

Medical support facilities are medical infrastructure at hospitals according to the patients' medical needs. Some medical support facilities include radiology equipment, ultrasound, CT scan, OK or VK, ECG, ICU or NICU, hemodialysis equipment, laboratory, endoscopy, and pharmacy. The hospitalized patients are in need of medical support facilities to help the treatment process and accelerate healing. If the patients were discharged, they will not get the proper medical support facilities and jeopardize themselves. 
This research found that the patients with the diagnosis of type 2 diabetes mellitus were mostly DAMA patients get the recommended support facilities namely haemodialysis, laboratory, endoscopy and pharmacy. Most discharged patients with febrile seizures got supporting facilities, such as laboratory and pharmacy. Meanwhile, patients with tuberculosis diagnosis received ECG, ICU, laboratory and pharmacy as the supporting facilities. On the one hand, five DAMA patients with a typhoid fever diagnosis received ICU, laboratory and pharmacy facilities.

Beside the laboratories and pharmacy, most DAMA patients also got ICU facilities. In the ICU room, the patients' family could not visit at any time because the patients were placed alone to cure their illness. It can be a psychological distraction for the patients because they cannot see their family at all times. As a result, they asked for being discharged without doctors' permit because of the discomfort in the ICU.

DAMA occurs due to many factors. Giving patients information about their disease and the danger of illness if left untreated as well as advising them to move to a cheaper room type are alternatives to reduce DAMA. It is necessary to ask patients' reason for being discharged so that the information will later be used by the hospital for DAMA policy evaluation.

\section{CONCLUSION}

DAMA patients at type A hospital in Surabaya from February 20 to March 20, 2012 were 88 people, but only 77 patients had medical records. The discharged patients mostly stayed in room type 3 because they should pay cheaper than other types. DAMA patients were mostly general patients who paid the medical expenses on their own.

The number of DAMA patients in room type 3 was $25 \%$ out of 88 discharged patients. Based on the payment type, $65 \%$ of DAMA patients paid the treatment fees using general payments. Since the patients paid on their own, they think they had a right to decide whether to stay or discharge. Based on the disease diagnosis, $12 \%$ discharged patients were diagnosed to suffer from type 2 diabetes mellitus. These patients were discharged wihtout doctors' permit because they thought that they could perform type $2 \mathrm{DM}$ treatment alone at home and felt recovered even not so. DAMA patients also lost the opportunity to get proper medical and non-medical services, such as the loss of laboratory, pharmacy, and endoscopy, ICU, ECG, CT scan, and other facilities.

The hospital can prevent DAMA by making a DAMA policy, notifying the patients' condition so that they know their health condition, informing them the importance of disease treatment and the risks of untreated diseases, and asking their reasons of discharging themselves so that the health personnel can use the information as a preventive program evaluation.

The current regulation of BPJS was different from JKN regulation. DAMA patients cannot get a claim from BPJS and be considered general patients. DAMA results in an opportunity loss because the hospital cannot adequately provide services to patients. As just the hospital got the opportunity loss, the patients also did the same because of the unfulfilled treatment.

BPJS regulation is expected to reduce the DAMA incidences since they may affect service utilization, examination and procedures. If DAMA still occurs, the medical procedures shall be carried out from the beginning again, and thus cause in the increase of health finance, longer evaluation system of disease (infectious diseases will riskily be transmitted to others). The readmission causes overutilization, and the cost of health services is more expensive because of the repetitive service procedures. The repetitive procedures will undoubtedly be very detrimental to both patients and hospital.

\section{CONFLICT OF INTEREST}

The authors declare that they have no conflict of interests.

\section{REFERENCES}

Abuzeyad, F. H. et al. (2017) 'The rate and reasons for discharge against medical advice', Bahrain Medical Bulletin, 39(3), pp. 140-145. doi: 10.12816/0047628.

Ak, I., S, M. A. and Z, C. (2016) 'Factors Associated with Discharge Against Medical Advice from Emergency Department , Universiti Kebangsaan Malaysia Medical Centre', Med \& Health, 11(1), pp. 29-37. doi: 10.17845/MH.2016.1101.05.

Atmiroseva and Nurwahyuni, A. (2017) 'Inpatient Readmission Insidence of National Health Insurance Patients at Partner Hospitals of BPJSHealth in Sukabumi 2015', Journal of Indonesian Health Policy And Administration, 2(2), pp. 20-24. doi: 10.7454/ihpa.v2i2.1909.

Azami-Aghdash, S. et al. (2016) 'Frequency and causes of discharges against medical advice from hospital cardiac care units of East Azerbaijan, Iran', Journal of Analytical Research in Clinical Medicine, 4(2), pp. 9096. doi: 10.15171/jarcm.2016.015.

Bahadori, M. et al. (2013) 'Discharge against Medical Advice: A Case Study in a Public Teaching Hospital in Tehran, Iran in 2012', Global Journal of Health Science, 5(6), pp. 179-185. doi: 10.5539/gjhs.v5n6p179.

Byun, H. (2016) Discharge Against Medical Advice: Associations With Selected Outcomes And The Role Of Hospital Characteristics. Johns Hopkins University.

Elshehry, A. F., Hassan, M. A. and Jawaid, R. F. (2017) 'The Rate and Reasons for Discharge against Medical Advice', Bahrain Medical 
Bulletin, 39(3), pp. 140-145. doi: $10.12816 / 0047628$.

Ministry of Health of the Republic of Indonesia (2014) Peraturan Menteri Kesehatan Republik Indonesia Nomor 28 Tahun 2014 Tentang Pedoman Pelaksanaan Program Jaminan Kesehatan Nasional, Law of Ministry of Health of the Republic of Indonesia. Indonesia. doi: 10.1192/bjp.205.1.76a.

Ndu, I. K. et al. (2016) 'Discharge Against Medical Advice ( DAMA ) Among the Paediatric Age Group in Enugu State University Teaching Hospital Parklane , Enugu', Journal of Experimental Research, 4(1), pp. 55-62. Available at: https://www.researchgate.net/publication/304 254232_Discharge_Against_Medical_Advice _DAMA_Among_the_Paediatric_Age_Group in_Enugu_State_University_Teaching_Hos pital_Parklane_Enug.

Popoola, S. O. et al. (2013) 'Leave against medical advice (LAMA) from in-patient orthopaedic treatment', SA Orthopaedic Journal, 12(3), pp. 58-61.

Prakoso, S. (2013) Analisis Opportunity Cost Pasien Pulang Paksa di Instalasi Rawat Inap RSU Haji Surabaya. Universitas Airlangga. Available

at: http://repository.unair.ac.id/23203/.

Sayed, M. El et al. (2016) 'Discharge Against Medical Advice From the Emergency Department: Results From a Tertiary Care Hospital in Beirut, Lebanon', Medicine Observational Study, 95(6), pp. 1-5. doi: 10.1097/MD.0000000000002788.

Widiarti, A. S., Lestari, T. and RMD, R. (2014) 'Analisis Kejadian Pasien Pulang Paksa Di Rumah Sakit Tni Au Lanud Iswahjudi Tahun 2013', Jurnal Rekam Medis, 8(2), pp. 13-21.

Xu, X., Yan, H. and Chan, C. K. (2017) 'Opportunity loss minimization and newsvendor behavior', Discrete Dynamics in Nature and Society, 2017, pp. 1-12. doi: 10.1155/2017/3481869. 